ENCYCLOPEDDIE Encyclopédie berbère

BERBERE

1 | 1984

1 | Abadir - Acridophagie

Abū Yūsof Ya'qūb, le Mérinide

(Voir Mérinides)

C. Agabi

\title{
OpenEdition
}

Journals

Édition électronique

URL : http://journals.openedition.org/encyclopedieberbere/806

DOI : $10.4000 /$ encyclopedieberbere.806

ISSN : 2262-7197

Éditeur

Peeters Publishers

Édition imprimée

Date de publication : 1 novembre 1984

Pagination : 96

ISBN : 2-85744-201-7

ISSN : $1015-7344$

Référence électronique

C. Agabi, «Abū Yūsof Ya'qūb, le Mérinide », Encyclopédie berbère [En ligne], 1 | 1984, document A35, mis en ligne le 01 décembre 2012, consulté le 05 octobre 2020. URL : http://journals.openedition.org/ encyclopedieberbere/806 ; DOI : https://doi.org/10.4000/encyclopedieberbere.806

Ce document a été généré automatiquement le 5 octobre 2020.

(c) Tous droits réservés 


\section{Abū Yūsof Ya'qūb, le Mérinide}

\section{(Voir Mérinides)}

\section{Agabi}

1 Dernier fils de 'Abd el-Haqq et successeur d'Abū Yahya après avoir supplanté son neveu (1258). Sa première action fut de déloger les Espagnols de Salé dont ils s'étaient emparés en profitant des querelles de succession. Le principal adversaire demeurait l'Almohade qui, sur la défensive, incite Yaghmorasan à attaquer, de l'est, les territoires mérinides. Abū Yūsof ayant battu Yaghmorasan s'empare enfin de Marrakech en 1269. Ses fils font reconnaître son autorité par les tribus du Haut-Atlas et du Sous ; les Arabes Ma'qil du Dra' se soumirent en 1271 à la suite d'une expédition conduite par Abū Yūsof en personne. La conquête de Sijilmasa en 1274 rejette les 'Abd el-Wadides plus à l'est.

2 Mais la puissance mérinide ainsi affermie ne pouvait négliger les questions ibériques. En 1272 les Naçrides, bousculés par Alphonse X, avaient sollicité l'intervention des Maghrébins, tandis que de son côté Jaime d'Aragon conduisait une expédition sur le territoire de Murcie. Les premières armées marocaines traversent le Détroit en 1275, le gros de l'expédition suit en 1276, après signature d'un traité de paix qui interrompt pour quelques mois la lutte fratricide entre les deux dynasties zénètes des Mérinides et des 'Abd el-Wadides. Les Castillans sont battus mais d'autres expéditions se succèdent en 1277,1279 et 1282 . Au cours de cette dernière, qui avait été faite à la demande d'Alphonse $\mathrm{X}$ contre son fils révolté, Abū Yūsof ramena la couronne de Castille qui lui avait été remise en gage. L'année qui précéda sa mort, il conduisait encore une nouvelle expédition qui aboutit à une paix de compromis. Il mourut au cours de son retour, à Algésiras, en 1286.

3 Abū Yūsof est le véritable fondateur de la puissance mérinide. Il est aussi le fondateur de Fès Jdid (1276). Au cours de son règne fut édifié la grande mosquée de la ville nouvelle (1279) et celle de Meknès. 


\section{BIBLIOGRAPHIE}

Voir Mérinides.

INDEX

Mots-clés : Espagne, Maroc, Moyen Âge 